\author{
A.A. Kashkanov', V.M. Diorditsa ${ }^{2}$, V.Yu. Kucheruk ${ }^{3}$, \\ D.Zh. Karabekova ${ }^{4}$, A.K. Khassenov ${ }^{4}$, A.M. Sharzadin ${ }^{4}$ \\ ${ }^{I}$ Kharkiv National Automobile and Highway University, Ukraine; \\ ${ }^{2}$ Vinnytsia Research Forensic Centre of the Ministry of Internal Affairs, Ukraine \\ ${ }^{3}$ Vinnytsia National Technical University, Ukraine \\ ${ }^{4}$ E.A. Buketov Karaganda State University, Kazakhstan \\ (E-mail:a.kashkanov@gmail.com)
}

\title{
Inertial evaluation of the tyre-road interaction during emergency braking
}

\begin{abstract}
An improved method of evaluation of the parameters of braking efficiency in vehicles of M1 category has been proposed for expert examination of motor vehicle accidents. This method is based on the control of parameters which are able to significantly influence the friction processes in the contact tyre-road area. These parameters were discovered in the course of analysis of theoretical approaches to the evaluation of the quality of tyre-road interaction, analytical formulas used for evaluation of the main braking parameters (deceleration, stopping distance) as well as for experimental evaluation of parameters of inertia braking efficiency. The generalization of study results showed that existing expert methods of evaluation of the parameters of vehicle motion during emergency braking do not take into account the design of modern braking systems, tyres and psychological aspects of control of the braking process by a human operator. After processing experimental data, recommendations have been formed to improve the existing approaches and eliminate the discovered defects. The verification of the proposed recommendations allowed to establish the areas of their efficiency for M1 category vehicles on dry bituminous concrete and confirmed the need to conduct further studies for vehicles of other categories and other types and conditions of road surface within the framework of the developed general approach.
\end{abstract}

Keywords: friction forces, tyre, road surface, friction process, deceleration, stopping distance, expert examination of motor vehicle accidents.

\section{Introduction}

The expansion of volumes and application sphere of motor vehicles raises the possibility of increase in the human and material costs as a result of road accidents. According to the data of the World Health Organization, every year more than 1.35 million people (3700 people per day) die and tens of millions are hurt in road accidents. This organization predicts that in 2020 road accidents (RA) will take the third place in the world as a reason for loss of health after cardiovascular diseases and severe depression. Mortality caused by road accidents is the main reason of death in children and youth aged from 5 to 29 [1].

The motion of a vehicle on the roadway or in another locality can be viewed as an operation of the system «driver - vehicle - roadway - environment» (DVRE). A breakdown in the normal operation of each of the components of DVRE system leads to the loss of efficiency (decrease in the speed of motion, unjustified stops, increase in fuel consumption) or to road accidents (RA). In the majority of cases, braking systems of motor vehicles (MV) [2] are used to prevent road accidents and the efficiency of their work is limited by friction forces during the tyre-road contact. Friction processes in the contact tyre-road area primarily depend on the speed of vehicle motion, type and condition of tyres as well as type and condition of the roadway [3]. The quality of tyre-road interaction is evaluated by the adhesion coefficient (coefficient of static friction) as well as the coefficient of sliding friction (if the wheels are locked up) which is usually lower than the adhesion coefficient [4]. Different methods, means and technologies depending on the purpose and goal of studies are currently used to evaluate tyre-road interaction as well as braking properties of the vehicle.

The ability to evaluate with sufficient accuracy the quality of tyre-road friction is important for improvement of the operation of control and safety systems of the vehicle (anti-lock braking system (ABS), electronic stability program (ESP), adaptive cruise control (ACC), preventive safety systems), traffic control and road maintenance [4-8].

In the USA and Europe the information obtained from the electronic control, safety and comfort systems of vehicles is successfully used to establish the circumstances of road accidents. It became possible due to the development of technologies used to record vehicle motion during a road accident: GPS system for pinpointing vehicle location, Event Data Recorder (EDR) (for recording the data on the accidents) Auto- 
mated Crash Notification (CAN) (automated systems for notification of accidents)) [9-11]. Automated systems for recording traffic parameters help to ensure the high accuracy of the initial data in order to establish the mechanisms of certain emergency situations using the basic laws of motion $[9,12]$.

Practice shows that it is not always possible to use the information from electronic systems which record vehicle motion parameters during road accidents. According to the Best Practice Manual on Road Accident Reconstruction of the European Network of Forensic Science Institutes [15] the evaluation of tyre-road interaction may be performed by conducting an investigatory experiment in road conditions of the scene of action or in similar conditions. The goal of the experiment is to determine the adhesion coefficient and(or) braking efficiency parameters (stopping distance, deceleration) $[2,8,13,16]$ which characterize the friction processes during tyre-road contact.

If it is impossible to conduct an experiment, then the adhesion coefficient, deceleration and stopping distance may be determined according to the reference data of experimental and calculation values [15] or may be accepted as a normative established by the Traffic Rules and the Council Directive 71/320/EEC [4]. Braking efficiency parameters may be determined by calculations using the formulas known in the forensic science practice [16].

Thus, the modelling of the braking efficiency parameters of vehicles during road accident examination is associated with calculations when the expert uses measurement results given to him by an investigator or by the court as well as typical reference data as initial data. Reference data include parameters and coefficients, the numerical values of which are chosen by the expert himself from the special scientific, technical and reference literature based on the nature and conditions of the road accident. The list of such characteristics and parameters includes the indices which characterize the braking efficiency of the vehicle (delay in the brake system response, deceleration increase time, constant deceleration), driver reaction time; indices of quality and condition of the road surface, coefficient of tyre-road adhesion, information on the speed of pedestrian motion, slip angles and radii of road turns etc.

In order to evaluate the braking efficiency, the expert just needs to calculate certain parameters by using formulas known from the theory of the operational characteristics of the vehicle $[14,15,16]$. However, only if the initial data are accurate and the calculation method has been chosen correctly, then it can be said that export conclusions are valid, objective and accurate and can be used as proof.

The main difference between the braking efficiency in modern vehicles in comparison and the braking efficiency in outdated vehicles which are not even equipped with ABS, is one of the subjects studied in this thesis. The purpose of the study is to improve the quality of vehicle expert examination after road accidents by improving outdated expert methods of evaluation of the vehicle motion parameters during braking based on the analysis of the parameters of tyre-road interaction during emergency braking.

The following tasks were performed to achieve the set goal:

- analysis of theoretical principles of formation of the parameters of tyre-road interaction during braking;

- experimental study of braking efficiency parameters in the operated vehicles;

- processing of experimental study results and issuing recommendations for improvement of the expert methods of evaluation of motion parameters of the modern vehicles during braking.

\section{Analysis of the principles of formation of tyre-road interaction parameters during braking}

A tyre is the only element used by the vehicle to interact with the road. The safety of motion is based on the ability to surmount high decelerations during braking and high transverse acceleration with respective lateral slips during a turn as well as on the ability to have minimal inclination for aquaplaning. According to the physical laws of friction, the friction which must be overcome to move an object on a flat surface depends only on the weight of the object (normal force having vertical influence on the surface) and the adhesion of materials between the foundation and the object. The quality of interaction between the foundation and the object is determined by dimensionless quantity, i.e. friction coefficient $(\mu)$. The low $\mu$ values indicate a smooth slippery surface of adherent materials with low friction. In case of high $\mu$ values, friction forces are increased and they must be overcome or transmitted (longitudinal, transversal forces or forces of lateral slips). The friction significantly determines the physics of driving of the vehicle at the beginning of the motion as well as during acceleration, deceleration and turns. The longitudinal and transversal forces are added vectorially to the resulting force transmitted from the tyre to the road (Fig. 1). The higher is the adhesive ability of the roadway and the tyre or the wheel load, the higher is the resulting force. 


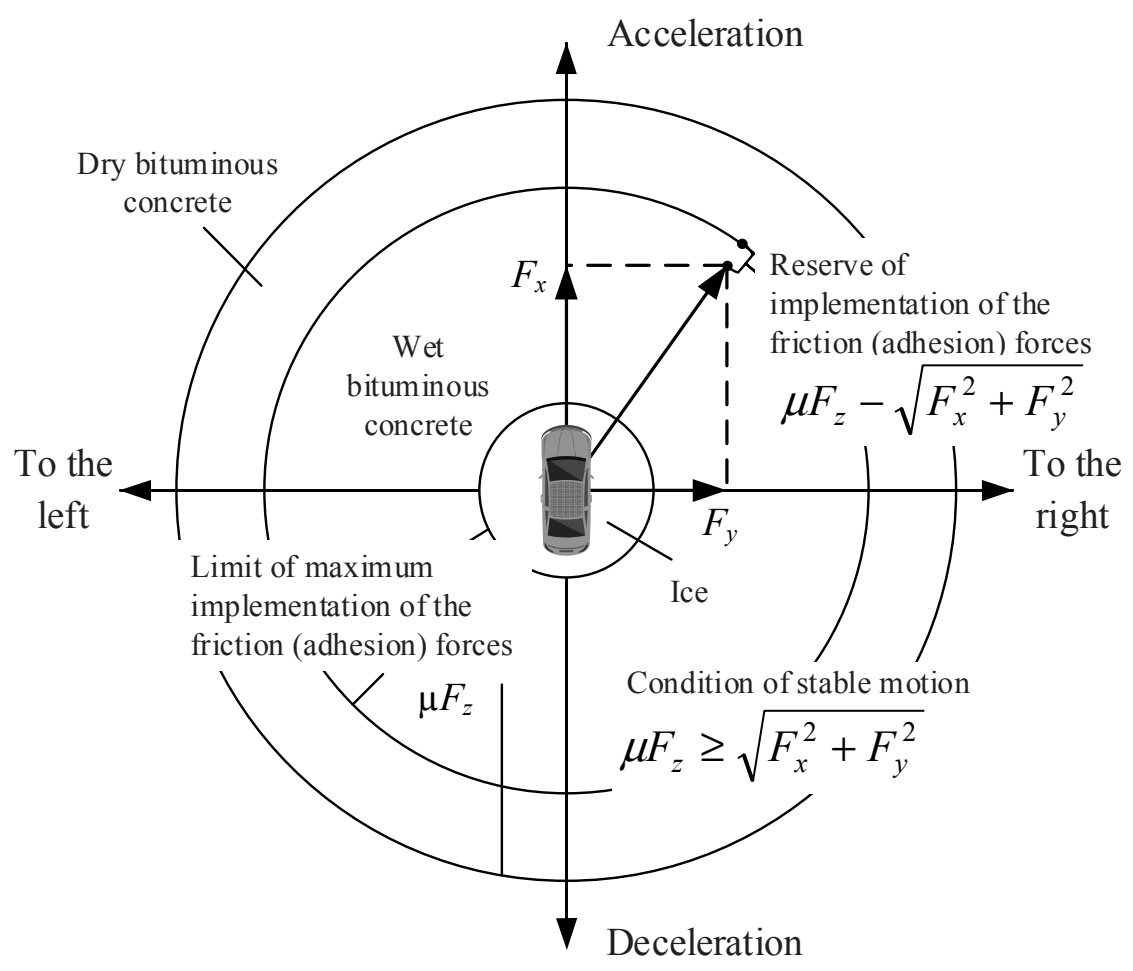

Figure 1. Forces in the tyre friction circle

Based on the Figure 1, the friction coefficient can be determined by using the value of friction forces in the transversal and longitudinal directions as well as the wheel load

$$
\mu=\sqrt{F_{x}^{2}+F_{y}^{2}} / F_{z} \text {. }
$$

If Burkhardt's method is used [13]

$$
\mu=\left(c_{1} \cdot\left(1-e^{-c_{2} \cdot s}\right)-c_{3} \cdot s\right) \cdot e^{-c_{4} \cdot s \cdot v} \cdot\left(1-c_{5} \cdot F_{z}^{2}\right),
$$

where $c_{1}, c_{2}, c_{3}$ are coefficients depending on the road surface quality; $c_{4}$ is coefficient depending on the maximum vehicle speed; $c_{5}$ is coefficient depending on the wheel load; $v$ is vehicle motion speed; $s$ is longitudinal sliding of the wheel.

If the angle of lateral tyre slip $\gamma$ and lateral tyre stiffness $C_{\gamma}$ are known, then the coefficient of lateral friction $\mu_{y}$ is determined by using the following equation

$$
\mu_{y}=\gamma \cdot C_{\gamma} / F_{z} \text {. }
$$

Deceleration during braking is determined by laws of mechanical motion and is limited by the ability of vehicle tyres to adhere to the road surface

$$
j=\left(v_{1}-v_{2}\right) / t_{b}=\left(v_{1}^{2}-v_{2}^{2}\right) /\left(2 S_{b}\right) \leq g \cdot(\mu \cdot \cos \alpha \pm \sin \alpha),
$$

where $v_{1}, v_{2}$ is initial and final vehicle speed; $t_{b}$ is braking time; $S_{b}$ is stopping distance; $g$ is free fall acceleration; $\alpha$ is road incline angle; «-» symbol is accepted for downward motion, «+» is accepted for upward motion.

The Stopping distance under stable deceleration is determined using the following equation

$$
S_{b s}=0.5 \cdot j \cdot t_{b}^{2}=v_{a}^{2} /(2 \cdot j),
$$

and according to the US standard [17] for vehicle speed $v_{a}$ in $\mathrm{km} / \mathrm{h}$

$$
S_{b s}=0.039 \cdot v_{a}^{2} / j \text {. }
$$

According to the Best Practice Manual on Road Accident Reconstruction of the European Network of Forensic Science Institutes the braking length [15] is determined by using the following formula

$$
S_{b}=\left(t_{a}+0.5 \cdot t_{g d}\right) \cdot v_{a}+v_{a}^{2} /(2 \cdot j),
$$

where $t_{a}$ is brake response time; $t_{g d}$ is deceleration increase time. 
Antilock braking system became one of the first and most important systems designed to reduce the stopping distance. ABS is a system equipped with control devices giving feedback which prevent the wheels from locking up during braking, as well as help to maintain the controllability and roadholding ability of the vehicle. The point of optimum braking efficiency is between two boundary situations, i.e. free rolling of the wheel and its full lockup. The difference between the speed of the vehicle and the speed of the wheel during braking is called longitudinal wheel slip, its optimum value during adhesion is within the limits of $10-30 \%$ [4].

\section{Results of experimental study of the parameters of vehicle braking efficiency}

The stable deceleration is the main parameter used to evaluate the braking efficiency of a vehicle. This parameter allows the expert to objectively evaluate the length of braking (stopping) distance of the vehicle and its speed of motion during emergency braking. Experimental data on vehicle braking dynamics was collected in the period from 2014 to 2018. These data were obtained by using certified special modern devices (Fig. 2): MAHA VZM-100, MAHA VZM-300 as well as the mobile recording and measuring set of Kharkiv National Automobile and Highway University [18] which allows to test the durability, controllability, ride smoothness, as well as aerodynamic, power, braking, hauling and speed properties of motor vehicles under UN Global Technical Rules No. 8 [19]. Experimental studies were mainly conducted with a visit to the scene of a road accident, the road conditions were similar to those of the road accident. Special attention was given to vehicles equipped with $\mathrm{ABS}$ and the type of the used tyres. The technical condition of vehicles was in compliance with the traffic rules.
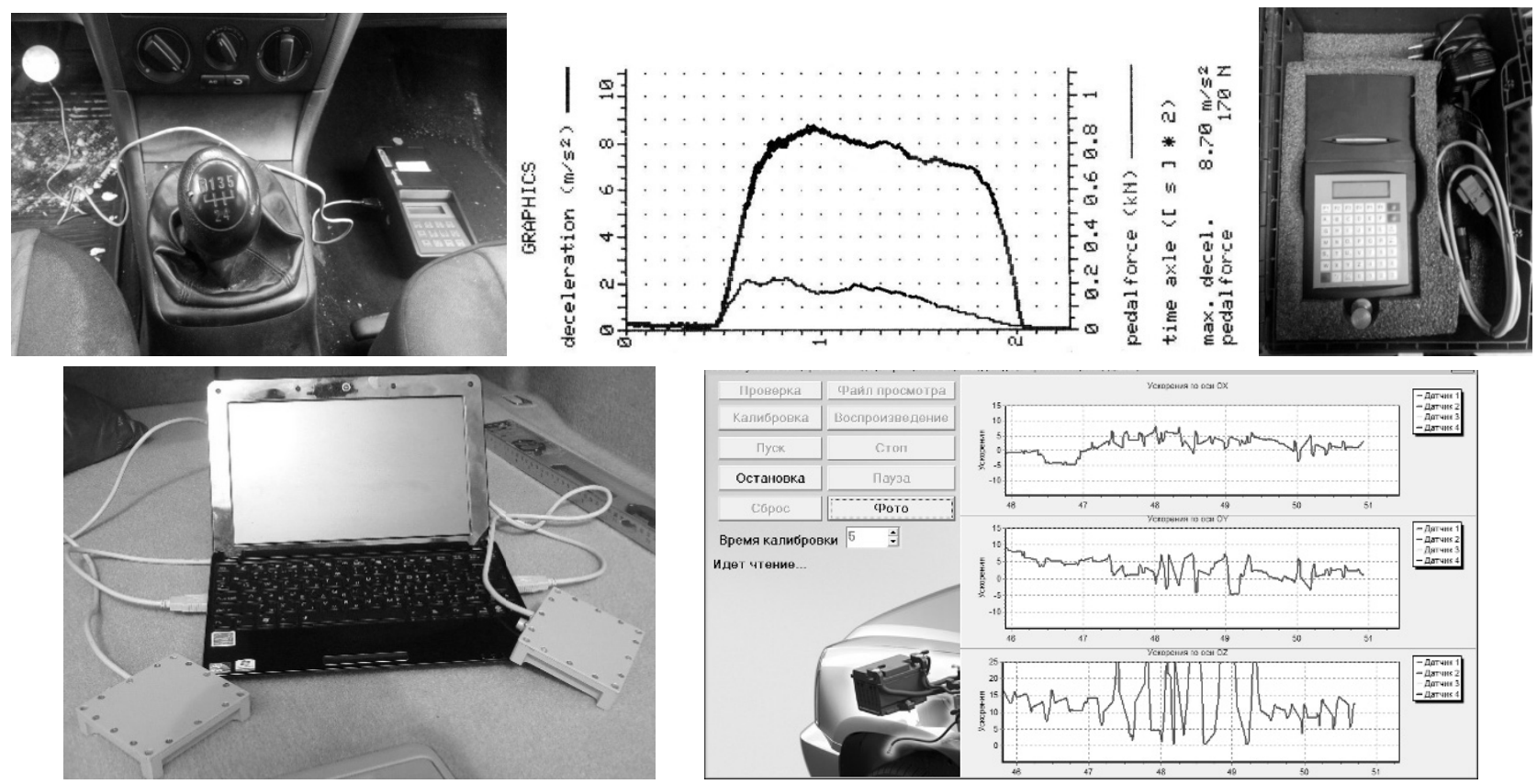

Figure 2. Devices for measuring the dynamics of vehicle braking

The study was conducted on 198 vehicles of M1, M3, N1, N2, N3, N3+O categories on different road surfaces. Model years were from 1975 to 2012. The total number of measurements of the stable deceleration of vehicles and the number of the studied vehicles (in brackets) are shown in Table 1.

T a b l e 1

Number of performed tests (studied vehicles)

\begin{tabular}{|l|c|c|c|c|c|c|}
\hline \multirow{2}{*}{ Road surface } & \multicolumn{5}{c|}{ Vehicle category } \\
\cline { 2 - 7 } & M1 & M3 & N1 & N2 & N3 & N3+O \\
\hline Dry bituminous concrete & $306(72)$ & $28(8)$ & $46(12)$ & $44(11)$ & $32(9)$ & $20(6)$ \\
\hline Wet bituminous concrete (0,2 mm film) & $114(32)$ & $24(7)$ & $22(3)$ & $24(7)$ & $4(1)$ & - \\
\hline Smoothed snow & $76(18)$ & - & $14(2)$ & $6(1)$ & - & - \\
\hline Black ice & $28(7)$ & - & $8(1)$ & $4(1)$ & - & - \\
\hline
\end{tabular}


The results of generalization of the conducted studies are shown on Figures 3-5 and in Table 2. The results were analysed using MS Excel. The shown parameters were calculated using $95 \%$ confidence level. The processing of study results showed that the process of vehicle braking is stochastic and is very well described by the normal law.

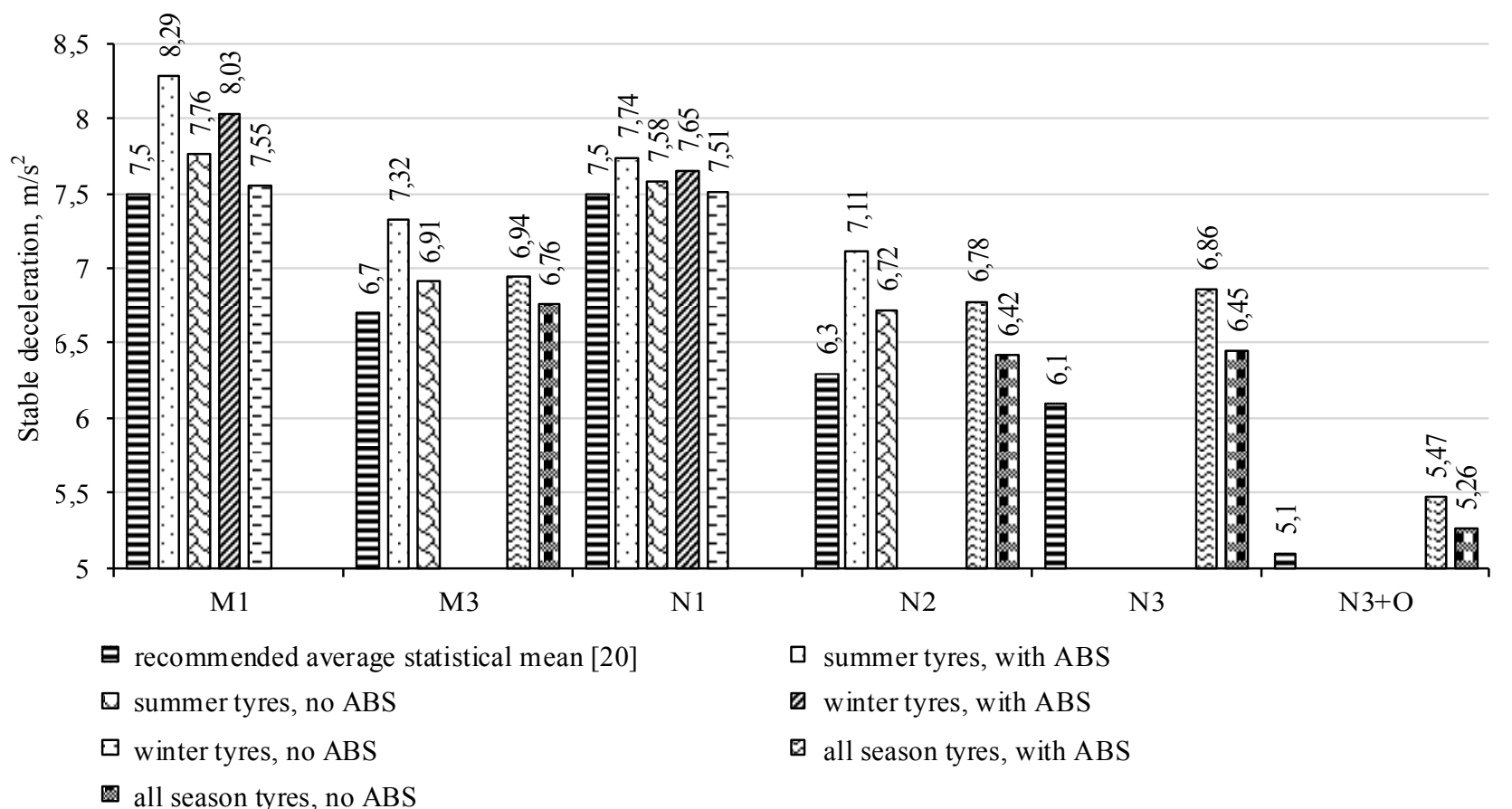

Figure 3. Average indices of stable deceleration on the dry bituminous concrete

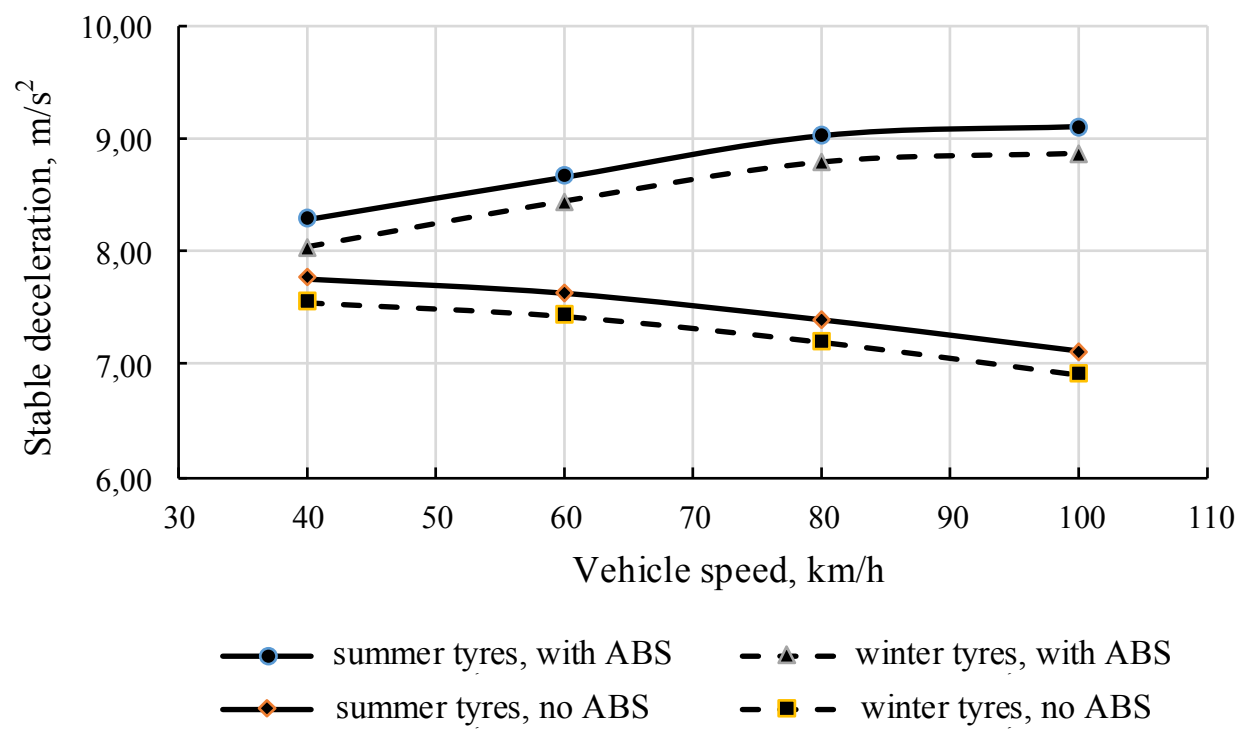

Figure 4. Average indices of stable deceleration in vehicles of M1 category on dry bituminous concrete 


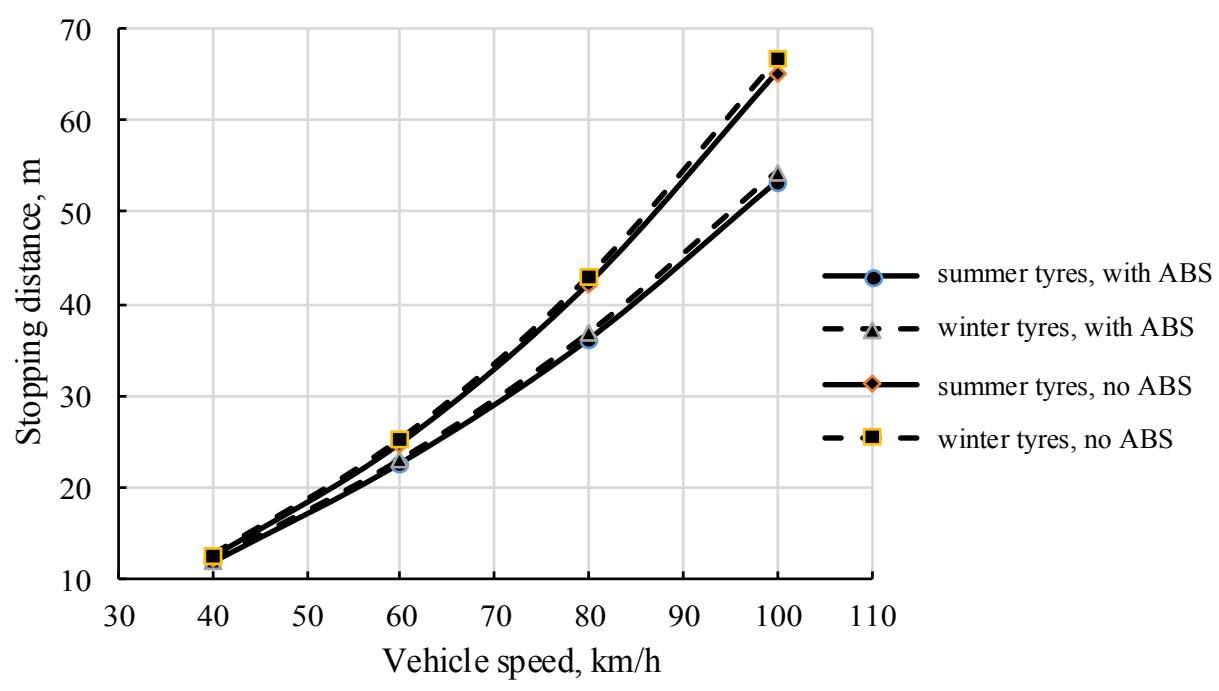

Figure 5. Average indices of stopping distance for vehicles of M1 category on dry bituminous concrete

Ta a le 2

Average indices of stable deceleration of vehicles of M1 category on different types of surface, $\mathrm{m} / \mathrm{s}^{2}$

\begin{tabular}{|c|c|c|c|c|c|}
\hline \multirow{3}{*}{ Road surface } & \multicolumn{5}{|c|}{ Tyre type, ABS functioning } \\
\hline & \multicolumn{2}{|c|}{ Summer tyres } & \multicolumn{2}{|c|}{ Winter tyres } & \multirow{2}{*}{$\begin{array}{c}\text { Recommended } \\
\text { value [20] }\end{array}$} \\
\hline & with ABS & without ABS & with ABS & without ABS & \\
\hline Dry bituminous concrete & 8.29 & \begin{tabular}{|l|}
7.76 \\
\end{tabular} & 8.03 & \begin{tabular}{|l|}
7.55 \\
\end{tabular} & 7.5 \\
\hline Wet bituminous concrete $(0,2 \mathrm{~mm}$ film $)$ & 6.71 & 5.86 & 6.83 & 6.14 & 5 \\
\hline Smoothed snow & - & - & 3.11 & 2.98 & 2.5 \\
\hline Black ice & - & - & 1.7 & 1.65 & 1.5 \\
\hline
\end{tabular}

The analysis of the results presented on Figure 3 and in Table 2 shows that the recommended average statistical mean of stable deceleration for expert examination of road accidents are different from average experimental values. The difference between indices is $9.5-26.8 \%$ which is significant enough to form an expert conclusion on a specific road accident. In order to improve the objectivity of an expert examination, the type of tyres and design characteristics of vehicle braking system must be taken into consideration from the point of view of availability and functioning of modern electronic systems (ABS, ESP etc.).

As we can see on Figure 4, the deceleration of vehicles without ABS decreases as the speed of motion increases which correlates well with the data $[4,16]$. Vehicles equipped with ABS show the opposite tendency which is explained by the characteristics of the system functioning and the psychology of driving by a human operator during braking [21]. The data obtained for vehicles equipped with ABS correlate well with the results [14]. The difference in the indices for vehicles with ABS and vehicles without ABS makes almost $6 \%$ at the speed of $40 \mathrm{~km} / \mathrm{h}$, and $26 \%$ at the speed of $100 \mathrm{~km} / \mathrm{h}$. Summer tyres show a $3 \%$ better dynamics on the dry bituminous concrete than winter tyres. In case of wet bituminous concrete $(0,2 \mathrm{~mm}$ film), there is an opposite tendency: winter tyres show a $3 \%$ better braking dynamics than summer tyres and this tendency increases as long as the thickness of water film grows [4].

The stopping distance in vehicles equipped with ABS is less than in vehicles without ABS (Fig. 5). The difference between indices for vehicles with ABS and vehicles without ABS is almost $4 \%$ at the speed of $40 \mathrm{~km} / \mathrm{h}$ and $23 \%$ at the speed of $100 \mathrm{~km} / \mathrm{h}$. The difference between indices of stopping distances for summer and winter tyres on dry bituminous concrete is within the limits of $0.5 \%$.

\section{Forming recommendations for improving expert methods of evaluation of motion parameters of modern vehicles during braking}

The results of the conducted experimental studies show the need to take into consideration the type of tyres and functioning of ABS during the determination of braking parameters of vehicles which can influence the results of expert examination of vehicles. The equation (7) recommended to determine the stopping distance of a vehicle does not take into consideration the mentioned parameters and must be improved. 
The analysis of characteristics of functioning of modern ABS and the results of the conducted studies allows to propose the following range of improvements.

The following equation is proposed to determine the stopping distance in vehicles equipped with $\mathrm{ABS}$

$$
S_{b}=\left(t_{a}+0.5 \cdot t_{g d}\right) \cdot v_{a}+\frac{v_{a}^{2}-v_{s}^{2}}{2 \cdot j_{A B S}}+\frac{v_{s}^{2}}{2 \cdot j},
$$

where $j_{A B S}$ is stable deceleration with ABS turned on, $j$ is stable deceleration with ABS turned off; $v_{s}$ is maximum vehicle speed, its decrease results in ABS turning off, $v_{a}=15 \mathrm{~km} / \mathrm{h}$ [4].

$$
j_{A B S}=j \cdot\left(1+\left(1.7 \ln v_{a}-5.9\right) / j\right) \text {. }
$$

The following equation can be used to determine the stopping distance for vehicles without ABS

$$
S_{b}=\left(t_{a}+0.5 \cdot t_{g d}\right) \cdot v_{a}+\frac{v_{a}^{2}}{2 \cdot j_{v}},
$$

where $j_{v}$ is corrected stable deceleration of motion speed of a vehicle.

$$
j_{v}=j \cdot\left(1+\left(0.54-0.0119 \cdot v_{a}\right) / j\right) .
$$

The results of comparison of experimental data with calculations according to the proposed models (8)-(11) and the current method (7) are shown on Figures 6, 7.

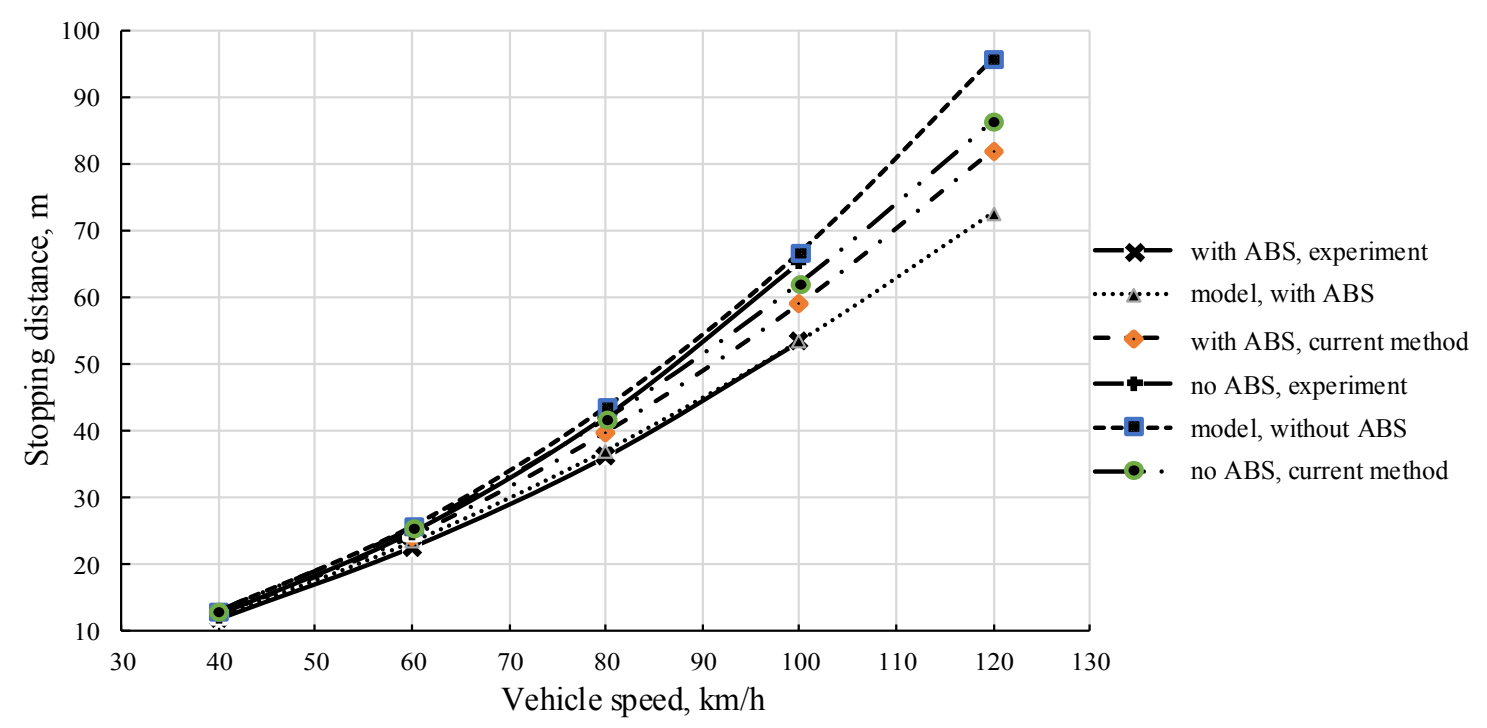

Figure 6. Results of evaluation of the stopping distance in vehicles of M1 category on dry bituminous concrete

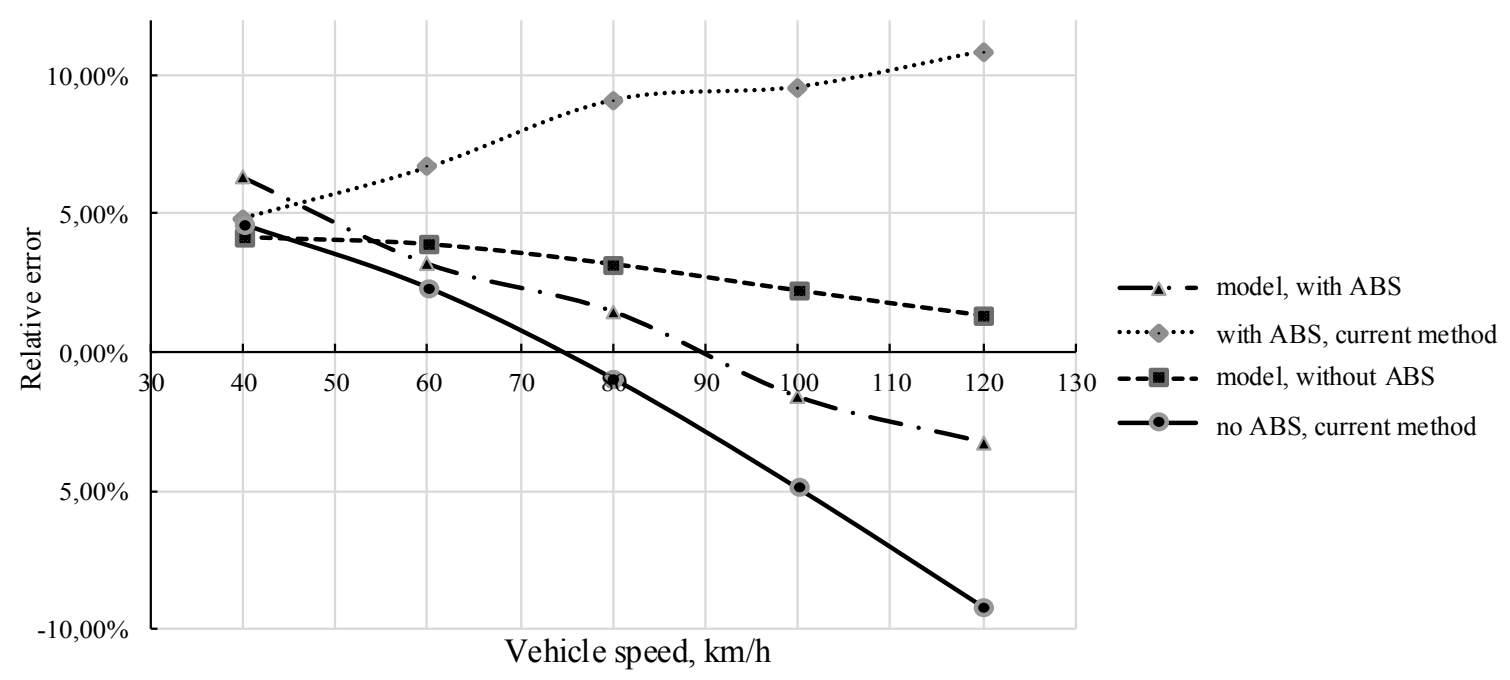

Figure 7. Error in the evaluation of the stopping distance in vehicles of M1 category on dry bituminous concrete 
The analysis of modelling results presented on Figures 6, 7 allows to recommend the equations (8) and (9) for vehicles of M1 category equipped with ABS during evaluation of braking efficiency parameters on dry bituminous concrete at the speed of $45 \mathrm{~km} / \mathrm{h}$ or higher. In case of lower initial speed of braking, it is advisable to apply the current method and use the equation (7). The equations (10) and (11) can be recommended for vehicles of M1 category which are not equipped with ABS during evaluation of braking efficiency parameters on dry bituminous concrete at the speed of $85 \mathrm{~km} / \mathrm{h}$ or higher. Otherwise, it is advisable to apply the current method and use the equation (7).

\section{Conclusions}

Tyre-road interaction during emergency braking is a complex dynamic process of stochastic nature. The quality of description of this process depends upon the full consideration of all ponderable factors: type and condition of road surface, type and condition of tyres, characteristics of vehicle design, initial braking speed, physiological characteristics of the driver etc.

The following conclusions can be drawn after analysing theoretical foundations of formation of the indices of tyre-road interaction during braking and experimental studies of indices of vehicle braking efficiency:

1. The development of vehicle structure and technologies of tyre production results in the improvement of indices of tyre-road interaction and requires regular renewal of the guidelines and methods for evaluation of motion parameters of modern vehicles during braking.

2. A general approach has been developed to improve the evaluation of efficiency parameters of braking in modern vehicles. The verification of this approach showed its efficiency for vehicles of M1 category on dry bituminous concrete, and specifically, for vehicles which are not equipped with ABS at the speed higher than $85 \mathrm{~km} / \mathrm{h}$, and for vehicles equipped with $\mathrm{ABS}$ at the speed higher than $45 \mathrm{~km} / \mathrm{h}$. In other cases, it is advisable to use the current method.

3. Further studies are needed to provide similar recommendations for other categories of vehicles and types of road surface.

\section{References}

1 World Health Organization. Road traffic injuries [Electronic resource]. - Retrieved from: http:/www.who.int/mediacentre/ factsheets/fs358/en/.

2 Кашканов А.А. Оцінка експлуатаційних гальмових властивостей автомобілів в умовах неточності вихідних даних: монографія / А.А. Кашканов, В.М. Ребедайло, В.А. Кашканов. - Вінниця: ВНТУ, 2010. — 148 с.

3 Rotshtein A. Fuzzy Expert System for Identification of Car Wheels Adhesion Factor with a Road Surface / A. Rotshtein, A. Kashkanov // Proceeding of the 6-th European Congress on Intelligent Techniques and Soft Computing. - Aachen, Germany. 1998. - P. 1735-1740.

4 Reif K. Bosch Automotive Handbook. 9th Edition / K. Reif, K.H. Dietsche. — Karlsruhe: Robert Bosch GmbH, 2014. 1544 p.

5 Singh K.B. An Intelligent Tire Based Tire-Road Friction Estimation Technique and Adaptive Wheel Slip Controller for Antilock Brake System / K.B. Singh, Ali Arat M., S. Taheri // Journal of Dynamic Systems Measurement and Control. - 2013. 135(3):031002-031002-26. doi:10.1115/1.4007704.

6 Singh K.B. Estimation of tire-road friction coefficient and its application in chassis control systems / K.B. Singh, S. Taheri // Systems Science \& Control Engineering. — 2015. — № 3:1. — P. 39-61. DOI: 10.1080/21642583.2014.985804.

7 Laugier C. Probabilistic analysis of dynamic scenes and collision risks assessment to improve driving safety / C. Laugier, I. E. Paromtchik, M. Perrollaz, J.D. Yoder, C. Tay, M. Yong et al. // IEEE Intelligent Transportation Systems Magazine. — 2011. No. 3. - P. 4-19.

8 Andersson M. Road friction estimation, Part II - IVSS project report [Electronic resource] / M. Andersson, F. Bruzelius, J. Casselgren, M. Hjort, S. Lofving, G. Olsson et al. - Retrieved from: http://fudinfo.trafikverket.se/fudinfoexternwebb/ Publikationer/Publikationer_001101_001200/Publikation_001109/IVSS_RFEII_Slutrapport.pdf.

9 Кашканов А.А. Автоматизовані системи повідомлення про ДТП та перспективи їх використання / А.А. Кашканов, В.А. Кашканов, О.Г. Грисюк // Сучасні технології в машинобудуванні та транспорті. - Луцьк: Луцький НТУ, 2016. № 1(5). - C. 78-82.

10 Marco P daSilva. Analysis of Event Data Recorder Data for Vehicle Safety Improvement [Electronic resource] / Marco P daSilva. - Retrieved from http://www.nhtsa.gov/DOT/NHTSA/NRD/ Multimedia/PDFs/EDR/Research/811015.pdf.

11 Hynd D. Study on the benefits resulting from the installation of Event Data Recorders [Electronic resource] / D. Hynd, M. McCarthy. - Retrieved from https://ec.europa.eu/transport/sites/transport/files/docs/study_edr_2014.pdf.

12 Struble D. Automotive accident reconstruction: practices and principles / Struble D. — Boca Raton: CRC Press, 2013. $498 \mathrm{p}$. 
13 Kemzuraite K. Investigation of dynamic properties of vehicle in various friction condition simulated with use of skidcar system / K. Kemzuraite, V. Zuraulis, D. Więckowski // The Archives of Automotive Engineering. — 2014. — No. 63(1). — P. 82-102.

14 Nerijus Kudarauskas. Analysis of emergency braking of a vehicle / Kudarauskas Nerijus // Transport. — 2007. — No. 22:3. — P. 154-159. DOI: 10.1080/16484142.2007.9638118.

15 European Network of Forensic Science Institutes. Best Practice Manual for Road Accident Reconstruction, ENFSI, ENFSIBPM-RAA-01. Version 01 - November 2015 [Electronic resource]. — Retrieved from: http://enfsi.eu/wp-content/uploads/2016/09/ 4._road_accident_reconstruction_0.pdf.

16 Пучкин В.А. Основы экспертного анализа дорожно-транспортных происшествий: База данных. Экспертная техника. Методы решений / В.А. Пучкин. — Ростов н/Д.: ИПО ПИ ЮФУ, 2010. — 400 с.

17 A Policy on Geometric Design of Highways and Streets. - AASHTO Green Book, 7th Edition, 2018. — 1047 p.

18 Пат. 51031 Україна, МПК G01P 3/00 25.06.2010. Система для визначення параметрів руху автотранспортних засобів при динамічних (кваліметричних) випробуваннях / Подригало М. А., Коробко А.И., Клец Д. М., Файст В.Л.; заявник та патентовласник Харківський нац. автом.-дорожн. університет. — № u 2010 01136; заявл. 04.02.10; опубл. 25.06.10, Бюл. № 12.

19 The United Nations Economic Commission for Europe. Global technical regulation United Nations № 8 «Electronic stability control systems»: Established in the Global Registry on 26 June 2008 [Electronic resource]. - Retrieved from: http:/www.unece.org/fileadmin/DAM/trans/main/wp29/wp29wgs/wp29gen/wp29registry/ECE-TRANS-180a8e.pdf.

20 Туренко А.М. Автотехнічна експертиза. Дослідження обставин ДТП: підручник для вищих навчальних закладів / А.М. Туренко, В.І. Клименко, О.В. Сараєв, С.В. Данець. - Харків: ХНАДУ, 2013. - 320 с.

21 Цыганков Э.С. 120 приемов контраварийного вождения / Э.С. Цыганков. - М.: РИПОЛ классик; Престиж книга, 2007. $-320 \mathrm{c}$

\author{
А.А. Кашканов, В.Н. Диордица, В.Ю. Кучерук, \\ Д.Ж. Карабекова, А.К. Хасенов, А.М. Шарзадин

\section{Шұғыл тежеу кезінде автокөлік дөңгелектерінің жолмен өзара әрекеттесуін инерциялық бағалау}

\begin{abstract}
Апатты жағдайларға автотехникалық сараптама жүргізу кезінде M1 санатындағы көлік құралдарын тежеу тиімділігінің параметрлерін бағалаудың жетілдірілген әдістемесі ұсынылды. Бұл әдістеме шинаның жолмен байланысқан аймағында үйкеліс процестеріне елеулі әсер ететін параметрлерді бақылауға негізделген. Бұл параметрлер автомобиль шиналарының жолмен өзара іс-қимыл сапасын бағалауға теориялық тәсілдерді талдау, тежелудің негізгі көрсеткіштерін (баяулау, тежеу жолы) бағалау және инерциялық әдіспен тежелу тиімділігінің көрсеткіштерін эксперименттік бағалау үшін аналитикалық формулалар негізінде анықталды. Зерттеу нәтижелерін жалпылау шұғыл тежеу кезінде автомобиль қозғалысының параметрлерін бағалаудың қолданыстағы сараптамалық әдістері заманауи тежегіш жүйелерінің, шиналар конструкциясының дамуын және тежеу процесін оператор-адамды басқарудың психологиялық аспектілерін ескермегенін көрсетті. Тәжірибелік деректерді өңдеу негізінде қолданыстағы тәсілдерді жетілдіру және анықталған кемшіліктерді жою бойынша ұсыныстар жасалды. Ұсынылған ұсынымдарды тексеру құрғақ битуминозды бетонда M1 санатындағы көлік құралдары үшін олардың тиімділік саласын белгілеуге мүмкіндік берді және әзірленген жалпы тәсіл шеңберінде басқа санаттағы көлік құралдары үшін әрі қарай зерттеулер жүргізу қажеттігін және жол жабынының басқа түрлері мен жағдайларын растады.
\end{abstract}

Кілт сөздер: үйкеліс күші, автомобиль шинасы, жол жабыны, тежеу процесі, баяулау, тежеу жолы, жол-көлік оқиғаларының сараптамасы.

\author{
А.А. Кашканов, В.Н. Диордица, В.Ю. Кучерук, \\ Д.Ж. Карабекова, А.К. Хасенов, А.М. Шарзадин
}

\title{
Инерционная оценка взаимодействия автомобильных шин с дорогой при экстренном торможении
}

\begin{abstract}
Предложена усовершенствованная методика оценки параметров эффективности торможения транспортных средств категории М1 при проведении автотехнических экспертиз аварийных ситуаций. Данная методика основана на контроле параметров, способных существенно повлиять на процессы трения в зоне контакта шины с дорогой. Данные параметры были выявлены на основе анализа теоретических подходов к оценке качества взаимодействия автомобильных шин с дорогой, аналитических формул для оценки основных показателей торможения (замедление, тормозной путь) и экспериментальной оценки показателей эффективности торможения инерционным методом. Обобщение результатов исследований показало, что существующие экспертные методы оценки параметров движения автомобилей при экстренном торможении не учитывают развития конструкции современных тормоз-
\end{abstract}


ных систем, шин и психологические аспекты управления человеком-оператором процессом торможения. На основе обработки экспериментальных данных были сформированы рекомендации по усовершенствованию существующих подходов и устранению выявленных недостатков. Проверка предложенных рекомендаций позволила выявить зоны их эффективности для ТЗ категории М1 на сухом асфальтобетоне и подтвердила необходимость проведения дальнейших исследований для других категорий ТЗ и других типов и состояний дорожного покрытия в рамках разработанного общего подхода.

Ключевые слова: силы трения, автомобильная шина, дорожное покрытие, процесс торможения, замедление, тормозной путь, экспертиза дорожно-транспортных происшествий.

\section{References}

1 World Health Organization. Road traffic injuries. www.who.int Retrieved from http://www.who.int/mediacentre/ factsheets/fs358/en/.

2 Kashkanov, A.A., Rebedailo, V.M., \& Kashkanov, V.A. (2010). Otsinka ekspluatatsiinykh halmovykh vlastyvostei avtomobiliv $v$ umovakh netochnosti vykhidnykh danykh [Estimation of operational braking properties of cars in conditions of inaccuracy of initial data]. Vinnytsia: VNTU [in Ukrainian].

3 Rotshtein, A., \& Kashkanov, A. (1998). Fuzzy Expert System for Identification of Car Wheels Adhesion Factor with a Road Surface. Proceeding of the 6-th European Congress on Intelligent Techniques and Soft Computing (pp. 1735-1740). Aachen, Germany.

4 Reif, K., \& Dietsche, K.H. (2014). Bosch Automotive Handbook. 9th Edition. Karlsruhe: Robert Bosch GmbH.

5 Singh, K.B., Ali Arat, M., \& Taheri, S. (2013). An Intelligent Tire Based Tire-Road Friction Estimation Technique and Adaptive Wheel Slip Controller for Antilock Brake System. Journal of Dynamic Systems Measurement and Control, 135(3):031002031002-26. doi:10.1115/1.4007704.

6 Singh, K.B. \& Taheri S. (2015). Estimation of tire-road friction coefficient and its application in chassis control systems. Systems Science \& Control Engineering, 3:1, 39-61, DOI: 10.1080/21642583.2014.985804.

7 Laugier, C., Paromtchik, I. E., Perrollaz, M., Yoder, J.D., Tay, C., \& Yong, M., et al. (2011). Probabilistic analysis of dynamic scenes and collision risks assessment to improve driving safety. IEEE Intelligent Transportation Systems Magazine, 3, 4-19.

8 Andersson, M., Bruzelius, F., Casselgren, J., Hjort, M., Löfving, S., \& Olsson, G., et al. (2010). Road friction estimation, Part II - IVSS project report. fudinfo.trafikverket.se Retrieved from http://fudinfo.trafikverket.se/fudinfoexternwebb/Publikationer/ Publikationer_001101_001200/Publikation_001109/IVSS_RFEII_Slutrapport.pdf

9 Kashkanov, A.A., Kashkanov, V.A., \& Hrysyuk, O.G. (2016). Avtomatyzovani systemy povidomlennya pro DTP ta perspektyvy yikh vykorystannya [Automated systems of accidents notification and prospects for their use]. Suchasny tekhnologyi $v$ mashynobudubanni ta transprti - Modern technologies in mechanical engineering and transport, 1(5), $78-82$ [in Ukrainian].

10 Marco P daSilva. (2008). Analysis of Event Data Recorder Data for Vehicle Safety Improvement. www.nhtsa.gov Retrieved from http://www.nhtsa.gov/DOT/NHTSA/NRD/ Multimedia/PDFs/EDR/Research/811015.pdf.

11 Hynd, D., McCarthy, M. (2014). Study on the benefits resulting from the installation of Event Data Recorders. ec.europa.eu Retrieved from https://ec.europa.eu/transport/sites/transport/files/docs/study_edr_2014.pdf.

12 Struble, D. (2013). Automotive accident reconstruction: practices and principles. Boca Raton: CRC Press, 498.

13 Kemzuraite, K., Zuraulis, V., \& Więckowski, D. (2014). Investigation of dynamic properties of vehicle in various friction condition simulated with use of skidcar system. The Archives of Automotive Engineering, 63(1), 82-102.

14 Nerijus, Kudarauskas (2007). Analysis of emergency braking of a vehicle, Transport, 22:3, 154-159, DOI: $10.1080 / 16484142.2007 .9638118$.

15 European Network of Forensic Science Institutes (2019). Best Practice Manual for Road Accident Reconstruction, ENFSI, ENFSI-BPM-RAA-01. Version 01 - November 2015. enfsi.eu Retrieved from http://enfsi.eu/wp-content/uploads/2016/09/ 4._road_accident_reconstruction_0.pdf.

16 Puchkin, V.A. (2010). Osnovy ekspertnoho analiza dorozhno-transportnykh proisshestvii: Baza dannykh. Ekspertnaia tekhnika. Metody reshenii [Basics of expert analysis of road accidents: Database. Expert equipment. Solution Methods]. Rostov-onDon: IPO PI YUFU [in Russian].

17 A Policy on Geometric Design of Highways and Streets (2018). AASHTO Green Book 7th Edition, 1047.

18 Podryhalo, M.A., Korobko, A.I., Klets, D.M., \& Faist, V.L. (2010). Sistema dlia viznachennia parametriv rukhu avtotransportnikh zasobiv pri dinamichnikh (kvalimetrichnikh) viprobuvanniakh [System for determination of parameters of motion of motor transport means at dynamical (cvalimetric) tests]. Patent 51031 Ukraine, MPK G01P 3/00 25.06.2010; applicant and patent holder Kharkiv National Automobile and Highway University. No u 2010 01136; Decl. 04.02.10; Publ. 25.06.10, Bull. No. 12 [in Ukrainian].

19 The United Nations Economic Commission for Europe (2019). Global technical regulation United Nations № 8 «Electronic stability control systems»: Established in the Global Registry on 26 June 2008. www.unece.org Retrieved from $\mathrm{http} / /$ www.unece.org/fileadmin/DAM/trans/main/wp29/wp29wgs/wp29gen/wp29registry/ECE-TRANS-180a8e.pdf

20 Turenko, A.M., Klymenko, V.I., Sarayev, O.V., \& Danecz, S.V. (2013). Avtotekhnichna ekspertiza. Doslidzhennya obstavin DTP: pidruchnik dlya vishchikh navchalnikh zakladiv [Autotechnical examination. Investigation of accident-related problems]. Kharkiv: KhNAHU [in Ukrainian].

21 Tsygankov, E.S. (2007). 120 priemov kontravariinoho vozhdeniia [120 methods of emergency driving]. Moscow: RIPOL klassik, Prestizh kniga [in Russian]. 